\title{
Preliminary Studies on Insect Pest Incidence on Tomato in Bama, Borno State, Nigeria
}

\author{
D. M. Mailafiyaa ${ }^{1, \star}$, M. M. Degri ${ }^{1}$, Y. T. Maina ${ }^{1}$, U. N. Gadzama ${ }^{2}$, I. B. Galadima ${ }^{1}$ \\ ${ }^{1}$ Department of Crop Protection, Faculty of Agriculture, University of Maiduguri, \\ P.M.B. 1069, Borno State, Nigeria \\ ${ }^{2}$ Department of Biological Sciences, Faculty of Sciences, University of Maiduguri, \\ P.M.B. 1069, Borno State, Nigeria \\ *E-mail address: dmailafiya@gmail.com
}

\begin{abstract}
This study assessed the insect pest infestation of tomato during 2011 and 2012 in three localities namely Bula Kuliye, Kajeri and Soye of Bama Local Government Area, Borno State, Nigeria. Fifty plants were randomly checked per farmers' field for insect pest recovery and count. Sampling was carried out in five to nine farmers' fields per locality. With 38-52 \%, 9-62 \%, 13-39\% and 5-9 \% species composition respectively across localities, Helicoverpa armigera Hubner (Lepidoptera: Noctuidae) followed by Bemisia tabaci (Gennadius) (Hemiptera: Aleyrodidae) were more predominant insect pests of tomato in these localities over Tetranychus sp. (Acari: Tetranichidae) and Spodoptera litoralis (Boisd.) (Lepidoptera: Noctuidae). Total proportion of infested tomato plants per farmers' field ranged from 19-36\%, and was significantly higher in Bula Kuliye and Kajeri than in Soye. Total number of insect pests per plant/leave and bored fruits per farmers' field fell between 2-5 and 21-35, and likewise, was higher in Bula Kuliye and Kajeri than in Soye. Although tomato plant infestation and fruit damage were found to be moderate or high in these localities, future studies on the bionomics or population dynamics of these insects remain essential for establishing their economic status.
\end{abstract}

Keywords: Tomato; insect infestation; abundance; bored fruits; localities; insect pest management

\section{INTRODUCTION}

Tomato (Lycopersicon lycopersicon L. Kast) is a staple fruit vegetable grown in both small (i.e., home or backyard gardens) and commercial quantities across the sub-Saharan Africa. With about $90 \mathrm{KJ}$ energy, $1.0 \mathrm{~g}$ crude protein, $10 \mathrm{mg}$ calcium, $24 \mathrm{mg}$ phosphorous, $0.4 \mathrm{mg}$ iron, 1000 I.U. vitamin A., $0.05 \mathrm{mg}$ Thiamine, $0.04 \mathrm{mg}$ Riboflavin, $0.7 \mathrm{mg}$ Niacin, 25 $\mathrm{mg}$ vitamin C per $100 \mathrm{~g}$ fresh weight of tomato (Rubatzky and Yamaguchi, 1997; Schippers, 2006; Lale, In press), the fruits are a great source of energy and basic nutrients in the diet of humans. The average daily consumption of tomato in most Nigerian homes is about $18 \%$ of the whole consumed vegetables (Aja, 2012). Besides being eaten raw and fresh as salad, the processed paste or puree of tomato fruits are used in cooking various soups, stew or savory dishes, and also for producing fruit drinks, juice or ketchup. Tomato requires adequate 
sunshine and cool weather of about $24^{\circ} \mathrm{C}$ day and $18^{\circ} \mathrm{C}$ night mean temperatures for optimal growth, and as such, is largely irrigated during the cool off (dry)-season in marginal or unfavorable areas of production (Alamu, 1996). Although annually cultivated on over one million hectares during both rainy and off-seasons in Nigeria, (Aja, 2012; ATA, 2012), commercial tomato production largely occurs in parts of the northern region including Kano, Jigawa, Kaduna, Gombe, Sokoto, Bauchi, Zamfara, Katsina, Kebbi, Borno, Plateau and Benue states, where off-season traditional or furrow irrigation is well practiced (Denton and Swarup, 1983; Olasantan, 1992; ATA, 2012). Fruit yields of tomato grown with both organic manures (swine, poultry, rabbit manure or sewage sludge) and NPK fertilizer have been reported to range between 20 and 44 tons per hectare (Olasantan, 1992; Oikeh and Asiegbu, 1993; Hudu et al., 2002; Aja, 2012). However, seasonal monetary losses of between 1,490 and 17,555 naira per hectare have been recorded (Alamu, 1996; Lawan et al., 2011, cit. Lale, In press), to which insect pests attack by fruit worms or borers, army worms, leaf miners etc contribute greatly (Ogunjimi and Adekalu, 2002; Umeh et al., 2002).

Besides its cultivation by peasant farmers across Borno state, tomato is mainly grown at commercial scale along the shores of the Lake Chad and Alau, and also in parts of Abadam, Kukawa, Mobbar, Bama, Dikwa, Konduga, Monguno, Jere, Biu and Askira/Uba Local Government Areas (BOSG, 2013). Being an important cash and industrial crop, tomato production and trading not only creates employment and generates income to many of the inhabitants of these areas, they greatly contribute to poverty alleviation and food security in the immediate region and country at large (Denton and Swarup, 1983; BOSG, 2013). Yet, there is paucity of information concerning insect pests attack and their effects on tomato production in these areas. This study, therefore, assessed the infestation and number of insect pests associated with tomato grown in three localities of Bama Local Government Area, Borno state, Nigeria.

\section{MATERIALS AND METHODS}

Bama Local Government Area of Borno State, Nigeria, is situated at 302 meters above sea level and falls between latitude $11^{\circ} 30^{\prime}$ North and longitude $13^{\circ} 30^{\prime}$ East. Bama is surrounded by four other Local Government Areas (Dikwa, Gwoza, Kala Balge and Konduga) within the State, and in addition, shares border with two neighboring countries namely Chad and Cameroon. Bama, occupies a total land mass of 1,176 square kilometers and has an estimated population of 269,986 inhabitants (NPC, 2006). Many of the inhabitants in this area are farmers that cultivate vegetables including tomato, onion, carrot, garden egg, sorrel, amaranthus, okra etc. Of the 11 Districts (Abbaram, Bama (New and Old), Banki, Bararam, Dar-El-Jamal, Gulumba, Kote, Kumshe, Soye and Walasa) in Bama, tomato is mainly grown in six localities (Bula Kuliye, Gadangari, Kajeri, Mallamburi, Mayinti and Soye) under both rain fed and supplemented irrigation conditions or strict irrigation practice.

Data collection was carried out in randomly selected farmers' fields based on their availability and accessibility in three of the six earlier mentioned localities namely Bula Kuliye, Kajeri and Soye. Eight field visits were made over four months (September December) during 2011 to five, eight and nine farmers' fields respectively in Kajeri, Bula Kuliye and Soye. Eight field visits were further made over four months (October - January) during 2012 to five, eight and twelve farmers' fields respectively in Soye, Kajeri and Bula Kuliye. Within each farmers' field, 50 plants were randomly inspected for insect pest presence and numbers. Sampling was done by carefully and entirely examining each selected 
plant early in the morning (between 6:30 and 9:00 am) when whiteflies are particularly less active and much easier to spot and count. Spider mite count (from top- and under-surfaces) was based on 50 leaves (each per plant) randomly taken per farmers' field from the middle or top plant portions. Sampled insects were preserved in $70 \%$ alcohol and identified in the Entomology Laboratory, Department of Crop Protection, University of Maiduguri.

Data on plant infestation, number of insect pests and bored fruits were subjected to Mann-Whitney and Kruskal-Wallis analyses to test for differences between years and amongst insect pest species / localities, respectively. When significant at $\mathrm{P}<0.05$, the means were separated using Nemenyi test (Sokal and Rohlf, 2011).

\section{RESULTS}

All (four) insect pests recovered in the field are presented in Table 1. Helicoverpa armigera Hubner (Lepidoptera: Noctuidae) and Bemisia tabaci (Gennadius) (Hemiptera: Aleyrodidae) both occurred in all three localities with their proportions ranging from $38 \%$ in Kajeri to $52 \%$ in Soye and $9 \%$ in Bula Kuliye to $62 \%$ in Kajeri, respectively. Tetranychus sp. (Acari: Tetranichidae) and Spodoptera littoralis (Boisd.) (Lepidoptera: Noctuidae) occurred in two-thirds of the sampled localities with their proportions respectively ranging from $14 \%$ in Soye to $39 \%$ in Bula Kuliye and $5 \%$ in Bula Kuliye to $9 \%$ in Soye.

Table 1. Species composition of insect pests attacking tomato grown in three localities in Bama.

\begin{tabular}{lccc}
\hline & \multicolumn{3}{c}{ Percent (\%) composition } \\
\cline { 2 - 4 } Insect species & \multicolumn{3}{c}{ Locality } \\
\cline { 2 - 4 } & $\begin{array}{c}\text { Bula } \\
\text { Kuliye }\end{array}$ & Soye & Kajeri \\
\hline $\begin{array}{l}\text { Helicoverpa armigera Hubner } \\
\text { Tetranychus sp. (Acari: }\end{array}$ & 45.9 & 51.5 & 37.6 \\
$\begin{array}{l}\text { Tetranichidae) } \\
\text { Bemisia tabaci (Gennadius) }\end{array}$ & 39.2 & 13.6 & - \\
Spodoptera littoralis (Boisd.) & 9.5 & 25.8 & 62.4 \\
\hline
\end{tabular}

Mean percent plant infestation per farmers' field, as shown in Table 2, ranged from $1 \%$ caused by Tetranychus sp. during 2012 to $12 \%$ caused by H. armigera during 2011 in the same locality, Bula Kuliye. Based on insect species within each locality (per year and across (the total)), the mean percent plant infestation per farmers' field caused by $H$. armigera during $2011\left(\mathrm{H}_{3,392}=14.7, \mathrm{P}=0.009\right)$ and $2012\left(\mathrm{H}_{3,694}=16.2, \mathrm{P}=0.001\right)$ were significantly higher than rates caused by Tetranychus sp., B. tabaci and S. littoralis in Bula Kuliye. 


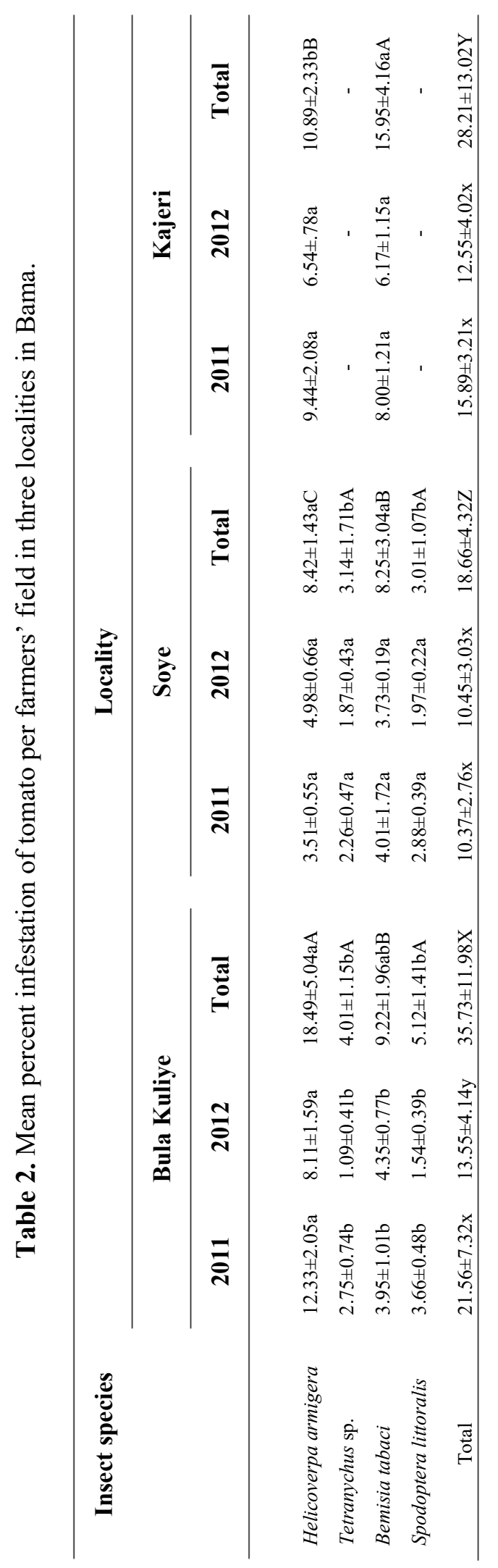




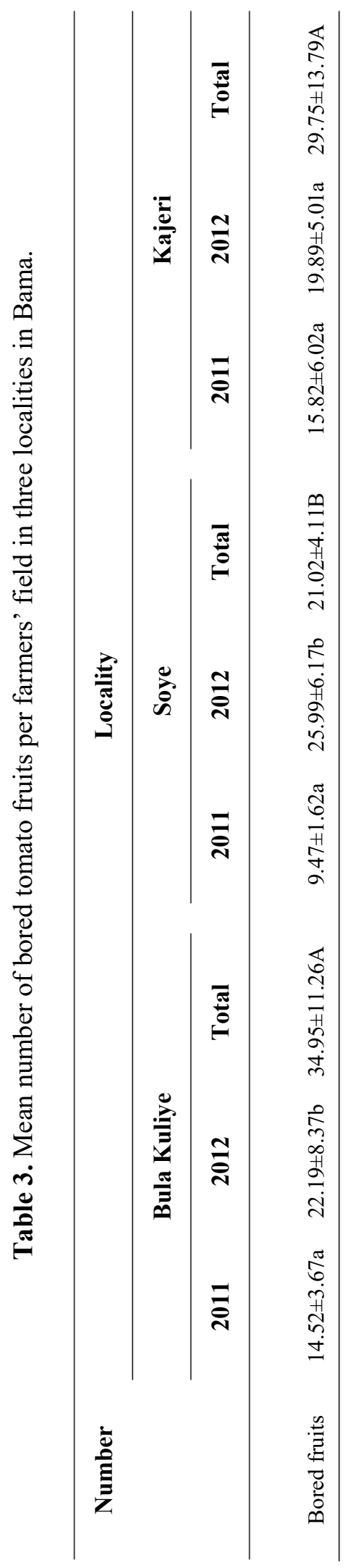




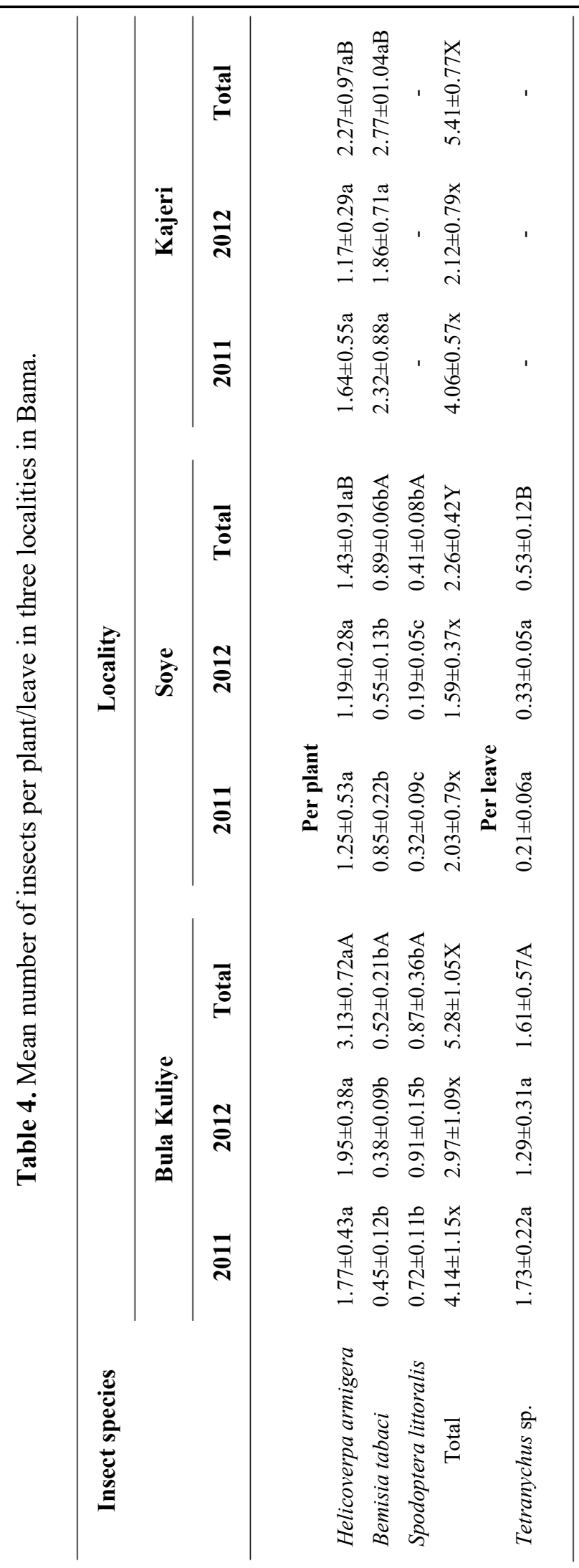


Mean percent plant infestation per farmers' field caused by the various insect pests recovered during 2011 and 2012 in Soye $\left(2011: \mathrm{H}_{3,445}=0.4, \mathrm{P}=0.3153 ; 2012: \mathrm{H}_{3,243}=0.1\right.$, $\mathrm{P}=0.422)$ and Kajeri $\left(2011: \mathrm{H}_{3,245}=1.3, \mathrm{P}=0.4117 ; 2012: \mathrm{H}_{3,393}=2.0, \mathrm{P}=0.132\right)$ were however not significantly different. Across years (2011 and 2012), mean total percent plant infestation per farmers' field varied significantly, and the rates caused by H. armigera and / or $B$. tabaci were generally higher in each locality (Bula Kuliye: $\mathrm{H}_{3,7981}=24.2, \mathrm{P}=0.001$; Soye: $\mathrm{H}_{3,5583}=22.1, \mathrm{P}=0.001$; Kajeri: $\mathrm{H}_{1,5185}=41.3, \mathrm{P}=0.001$ ).

Based on each insect species across localities, mean total percent plant infestation caused by $H$. armigera per farmers' field was significantly higher in Bula Kuliye and Kajeri than in Soye $\left(\mathrm{H}_{2}, 18532=32.9, \mathrm{P}=0.0015\right)$. For $\mathrm{B}$. tabaci, mean total percent plant infestation was significantly higher in Kajeri than in Bula Kuliye and Soye $\left(\mathrm{H}_{2,18532}=20.7, \mathrm{P}=0.0002\right)$. By contrast, the mean total percent plant infestation caused per farmers' field by Tetranychus sp. and S. littoralis were not significantly different in Bula Kuliye and Soye (Tetranychus sp.: $\mathrm{H}_{1,18532}=0.8, \mathrm{P}=0.5351 ;$ S. littoralis: $\left.\mathrm{H}_{1,18532}=1.5, \mathrm{P}=0.6413\right)$.

Across insect species and year per locality, whereas percent plant infestation by all the insect pests recovered was significantly higher during 2011 than 2012 in Bula Kuliye $\left(U_{1,7981}\right.$ $=11.7, \mathrm{P}=0.001)$, rates observed were not significantly different between years in Soye $\left(\mathrm{U}_{1}\right.$, $5583=1.9, \mathrm{P}=0.2841)$ and Kajeri $\left(\mathrm{U}_{1,5185}=1.3, \mathrm{P}=0.7432\right)$. Across years, insect species and localities, the mean total percent plant infestation per farmers' field caused by all insect pests recovered was significantly higher in Bula Kuliye, followed by Kajeri than in Soye $\left(\mathrm{H}_{2,18523}\right.$ $=46.1, \mathrm{P}=0.0005)$.

The mean number of bored tomato fruits by $H$. armigera and $S$. littoralis per farmers' field respectively ranged from nine during 2011 in Soye to 26 during 2012 also in Soye (Table 3). Across years per locality, the mean number of bored tomato fruits per farmers' field was significantly higher during 2012 than 2011 in both Bula Kuliye $\left(\mathrm{U}_{1,7981}=10.2, \mathrm{P}=\right.$ $0.0018)$ and Soye $\left(U_{1,5583}=5.7, P=0.0004\right)$, but not significantly different between years in Kajeri $\left(\mathrm{U}_{1,5183}=14.6, \mathrm{P}=0.3321\right)$. Across years and localities, the mean total number of bored tomato fruits per farmers' field ranged from 21 in Soye to 35 in Bula Kuliye, and was significantly lower in Soye than in both Bula Kuliye and Kajeri $\left(\mathrm{H}_{2,18532}=17.3, \mathrm{P}=0.0004\right)$.

Based on insect species within (per year) each locality, the mean numbers of $H$. armigera per plant was generally significantly higher than those of $B$. tabaci and $S$. littoralis during each and across both (total) years in Bula Kuliye $\left(2011: \mathrm{H}_{3,3198}=8.3, \mathrm{P}=0.0001\right.$; 2012: $\mathrm{H}_{3,4798}=13.2, \mathrm{P}=0.0011$; Total: $\left.\mathrm{H}_{3,7998}=4.0, \mathrm{P}=0.0107\right)$ and Soye $\left(2011: \mathrm{H}_{3,3598}=\right.$ 22.6, $\mathrm{P}=0.0003 ; 2012: \mathrm{H}_{3,1998}=5.9, \mathrm{P}=0.0001$; Total: $\left.\mathrm{H}_{3,559}=10.4, \mathrm{P}=0.0011\right)$ (Table 4). By contrast, in Kajeri, the mean numbers of $H$. armigera and $B$. tabaci per plant were not significantly different during each $\left(2011: \mathrm{H}_{1,1998}=0.7, \mathrm{P}=0.4781 ; 2012: \mathrm{H}_{1,3198}=1.1, \mathrm{P}=\right.$ 0.1152 ) and across both (total) years (Total: $\mathrm{H}_{1,5198}=0.4, \mathrm{P}=0.5111$ ). Similarly, the mean total (across species) numbers per plant of insect pests recovered during different years were not significantly different in Bula Kuliye $\left(\mathrm{U}_{1,7998}=0.5, \mathrm{P}=0.3165\right)$, Soye $\left(\mathrm{U}_{1,5598}=1.2, \mathrm{P}=\right.$ $0.8744)$ and Kajeri $\left(\mathrm{U}_{1,5198}=0.8, \mathrm{P}=0.1952\right)$. Across localities, mean total (across years and species) numbers per plant of all insect pests recovered was significantly higher in Bula Kuliye and Kajeri than in Soye $\left(\mathrm{H}_{2,18797}=46.1, \mathrm{P}=0.0012\right)$.

Also, whereas the mean numbers of Tetranychus sp. recovered per leave during each year were not significantly different in Bula Kuliye $\left(U_{1,7998}=0.5, P=0.3165\right)$ and Soye $\left(U_{1}\right.$, $5598=1.2, \mathrm{P}=0.8744)$, its total mean numbers across localities were significantly different $\left(\mathrm{H}_{1,13596}=16.5, \mathrm{P}=0.0001\right)$. 


\section{DISCUSSION AND CONCLUSIONS}

Present results provide basic information on insect infestation of tomato and the pattern of occurrence in Bama - Nigeria where the fruits are grown in commercial quantities and supplied to Maiduguri the Borno state capital, as well as various parts of the state and region for consumption or utilization. Hitherto, such data for the entire northern parts of Borno was scarce (Gambo et al., 2008). Based on their distribution and proportion of individuals across localities, $H$. armigera and B. tabaci, with between $38 \%$ and $62 \%$ of the insect pests found in all three studied localities (Bula Kuliye, Kajeri and Soye) seemed to be the predominant insect pests of tomato in this area. Although restricted to only two-thirds of the localities studied, Tetranychus sp., with $14 \%$ to $40 \%$ of the insect pests found tended to be more important also at least in some parts of the area compared to $S$. littoralis with less than $10 \%$ of individuals recovered. Similar to our results, Umeh et al. (2002) sampled the major insect pests of tomato in five states (Bauchi, Kaduna, Kano, Plateau and Oyo) situated in the northern and southern parts of Nigeria and reported $H$. armigera and $B$. tabaci to be predominant insect pests found in all the states compared to $S$. littoralis with the least recorded proportion of individuals amongst the species found. Also, with no more than four insect species infesting tomato cultivated in Bama situated in the savannah agroecological zone of Nigeria, our results somewhat support the argument of the above mentioned authors, that tomato production in the northern parts of the country is likely to be less prone to insect pest attack than in the southward parts (i.e., Oyo in the rain forest agroecological zone) where at least seven insect pest species were documented on tomato. This, because, compared to states in the savannah agroecological zone, relatively higher humidity (owing to heavier rainfall during the wet season) in the forest agroecological zone should support greater multiplication of pests and diseases, and also, the maintenance of vegetation diversity including off-season alternative hosts that harbor various developmental stages of insect pests'.

Contrary to the results of Umeh et al. (2002), who found aphids (A. gossypii Glover and Myzus persica Sulzer) and Zonocerus variegatus L. to be common in (at least four states) the savannah agroecological zone, no single recovery of either species was made in this study. Differences observed may however be connected to the cropping practices encountered in these studies. In the former study, tomato was generally interplanted with between four to seven other vegetables / tuber / cereal crops (pepper, onion, lettuce, carrot, cabbage, green pea, okra, amaranths, cassava, Celosia spp., maize and Corchorus spp.), whilst in this study tomato was mainly sole-cropped and only in a few cases interplanted with at the most one of the following three vegetables onion, amaranthus and sorrel.

Current results indicate that though mean percent plant infestation varied amongst the different insect species per locality, the total rates caused by these insects in each locality did not vary across years. Additionally, in being responsible each for between $8 \%$ and $18 \%$ tomato infestation per farmer's field, $H$. armigera and B. tabaci heavily contributed to the mean total rates (19-36\%) obtained in different localities. Results on mean total percent tomato infestation per farmer's field further falls within the ranges reported by Umeh et al. (2002) from crops grown in Bauchi (13-46\%), Kaduna (26-62 \%), Kano (20-36 \%), Plateau (8-40\%) and Oyo (10-65\%).

Results on higher mean number per plant of $H$. armigera singly or together with $B$. tabaci amongst insect species during each and across years respectively in one- to two-thirds of the studied localities, as well as the significantly varied mean total number per plant/leave of insect pests across localities (across years and species), but not between years per locality 
(across species) were not clearly understood. These differences were however thought to be influenced at least in part by the type and intensity of cultivation practices or control actions employed by various tomato farmers in this area. Future studies will be needed to confirm these, which in addition, should aid explain the reasons for none recovery of Tetranychus sp. and $S$. littoralis in Kajeri for instance with significantly higher mean values of tomato infestation and numbers of bored fruits or insect pests compared to Soye where all four insect species found in this study were recorded.

Regression analyses by Umeh et al. (2002) for instance showed that in Kaduna and Oyo, tomato infestation significantly decreased as the number of plant species intercropped with tomato increased. Other cultural practices such as the methods of land preparation and number of years certain fields were kept fallow or given treatments against pests, also did not influence the level of insect infestation. Insecticides utilization by farmers, characterized by inappropriate dosage application, likewise did not reduce insect pest problems. In spite of the few number of insect pests found in this study, results obtained indicate moderate to high plant infestation rates $(19-36 \%)$ and the number of damaged tomato fruits $(21-35)$ per farmer's field in this area. Furthermore, whiteflies, which happen to be predominant in these localities, are important vectors of the 'Tomato Yellow Leaf Curl Virus' and their infestation can result in the disease outbreak (Ssekyewa, 2006). These, put together, highlight the need for appropriate and effective insect pest management in this area.

\section{References}

[1] Aja, C. (2012). Tomato, The wonder fruit. Manufacturing Today. Available at: http://manufacturingtoday.com.ng/2013/04/16/tomato-the-wonder-fruit_3.pdf. (Accessed on $1^{\text {st }}$ July, 2013).

[2] Alamu, J.F. (1996). Marketing of fadama tomatoes, pepper and onions. A case study of Kano and Jigawa States of Nigeria. PhD Thesis. Department of Agricultural Economics and Rural Sociology, Ahmadu Bello University, Zaria, Nigeria.

[3] ATA (2012). Overview of Tomato production and ATA intervention in Nigeria. Agricultural Transformation Agenda (ATA). Available at:

http://www.fmard.gov.ng/index.php/issues-in-agriculture/95-overview-of-tomatoproduction-and-ata-intervention. (Accessed on $25^{\text {th }}$ July, 2013).

[4] BOSG (2013). Toursim and investment opportunities in Borno State, Volume 2. Ministry of Agriculture and Natural Resources. Available at:

http://bornostate.gov.ng/BS_Tourism_and_Investment_Opportunities.pdf. (Accessed on $23^{\text {rd }}$ July, 2013).

[5] Denton, O.A. and Swarup, V., Tomato cultivation and its potential in Nigeria. Acta Horticulturae 123 (1983) 257-263.

[6] Gambo, B.A., Yerima, F.A.K., Arjinoma, M. and Doro, A.K. (2008). Horticultural practices at the shores of Lake Chad. Journal of Sustainable Development in Agriculture and Environment, 3: 71-79.

[7] Hudu, A.I., Futuless, K.N. and Gworgwor, N.A. (2002). Effects of mulching intensity on the growth and yield of irrigated tomato (Lycopersicon esculentum Mill.) and weed infestation in semi-arid zone of Nigeria. Journal of Sustainable Agriculture, 21: 37-45. 
[8] Lale, N.E.S. (In press). Insect pest management in cultivated vegetables. In: The Socioeconomic sustainability of livelihood in the Lake Chad Basin. Proceedings of the Alexander Von Humboldt Kolleg International Conference (hosted by the University of Maiduguri, Borno State, Nigeria) held at DRACC, Abuja, Nigeria, $11-13^{\text {th }}$ December 2012.

[9] NPC (2006). 2006 Census Record. National Population Commission (NPC) Publication, Abuja.

[10] Ogunjimi, L.A.O. and Adekalu, K.O. (2002). Problems and constraints of small scale irrigation (Fadama) in Nigeria. Food Reviews International 18 (4): 295-304.

[11] Oikeh, S.O. and Asiegbu, J.E. (1993). Growth and yield responses of tomatoes to sources and rates of organic manures in ferralitic soils. Bioresource Technology, 45: 21-25.

[12] Olasantan, F.O. (1992). Vegetable production in traditional farming systems in Nigeria. Outlook on Agriculture, 21: 117-127.

[13] Rubatzky, V.E. and Yamaguchi, M. (1997). World vegetables: principles and nutritive values. 2nd edn. New York, USA, Chapman and Hall.

[14] Schippers, R.R. (2006). Traditional vegetables in Africa. In: Proceedings of the International Symposium on the Nutritional Value and Water Use of Indigenous Crops for Improved Livelihoods. 19-20 ${ }^{\text {th }}$ September, University of Pretoria. [CD ROM]. The Centre for Nutrition, University of Pretoria, Pretoria.

[15] Sokal, R.R. and Rohlf, F.J. (2011). Biometry: the principles and practice of statistics in biological research. 4 th edn. New York: W.H. Freeman and Co.

[16] Ssekyewa, C. (2006). Incidence, distribution and characteristics of major Tomato Leaf Curl and Mosaic Virus Diseases in Uganda. PhD-thesis. Faculty of Bioscience Engineering, Ghent University, Ghent, Belgium. 233 pp.

[17] Umeh, V.C., Kuku, F.O., Nwanguma, E.I., Adebayo, O.S. and Manga, A.A. (2002). A survey of the insect pests and farmers' practices in the cropping of tomato in Nigeria. Tropicultura, 20: 181-186. 